\title{
Analisis Peningkatan Kualitas dan Kapasitas Jaringan Seluler PT. XL Axiata pada Area Jawa Tengah bagian Utara melalui Proyek Swap dan Modernisasi
}

\author{
Eva Yovita Dwi Utami ${ }^{1}$, Pravita Ananingtyas Hanika ${ }^{2}$ \\ Program Studi Teknik Elektro, \\ Fakultas Teknik Elektronika dan Komputer, \\ Universitas Kristen Satya Wacana, Salatiga \\ 1eva.utami@staff.uksw.edu, ${ }^{2}$ irenepravita@yahoo.co.id,
}

\begin{abstract}
Ringkasan
Dengan meningkatnya jumlah pelanggan dan permintaan berbagai jenis layanan menuntut ketersediaan coverage, kapasitas dan kualitas jaringan komunikasi bergerak yang handal. Pembangunan Base Tranceiver Station (BTS) diperlukan agar operator mampu mencakup area lebih luas serta menyediakan kapasitas trafik yang mencukupi dan kualitas jaringan yang baik. Namun demikian pembangunan BTS baru seringkali mengalami permasalahan antara lain biaya yang mahal dan membutuhkan waktu yang cukup lama untuk mendapatkan ijin dari pemerintah maupun warga setempat. Proyek swap dan modernisasi di PT. XL Axiata Area Jawa Tengah bagian Utara merupakan sebuah proyek yang akan menukar perangkat 3G yang sebelumnya menggunakan BTS 3900 milik Huawei menjadi RBS 6000 milik Ericsson dan melakukan modernisasi perangkat 2G RBS 2000 menjadi RBS 6000. Dalam makalah ini akan dilaporkan hasil penelitian unjuk kerja jaringan seluler setelah dilakukannya proyek swap dan modernisasi ditinjau dari segi peningkatan kualitas dan kapasitas. Penelitian dilakukan di PT. XL Axiata Area Jawa Tengah bagian Utara pada cluster D5. Hasil penelitian menunjukkan peningkatan kualitas dilihat dari hasil drive test yaitu perbaikan $R x$ Qual sebesar 23,85\%, $E_{c} / N_{0}$ sebesar 4,02\% dan SQI sebesar $96,38 \%$. Selain itu terdapat penurunan persentase Call Drop Rate (CDR) dan kenaikan persentase Handover Success Rate. Peningkatan kapasitas diperoleh dari penambahan kanal karena adanya perubahan arsitektur hardware, yaitu sebelumnya BTS untuk 2G hanya mempunyai 12 TRX per modul DRU menjadi 24 TRX per modul DRU dan BTS untuk 3G sebelumnya 256 CE per modul WRFU (UL/DL) menjadi 512 CE per modul DUW (UL/DL). Jumlah trafik yang mampu ditangani jaringan setelah adanya proyek swap dan modernisasi meningkat sebesar 34328,21 Erlang untuk 2G dan 36451674 Erlang untuk 3G. Penambahan kapasitas juga menurunkan terjadinya blocked call, yang ditunjukkan dengan berkurangnya TCH Congestion Rate.
\end{abstract}

Kata kunci: kapasitas, kualitas, trafik

\section{Pendahuluan}

Base Transceiver Station (BTS) atau Radio Base Station (RBS) merupakan elemen penting dalam jaringan bergerak seluler karena menyediakan koneksi fisik berupa kanal radio untuk mobile station yang berada dalam cell site-nya [1]. Karena itu BTS harus mampu memberikan kualitas sinyal yang bagus dalam jangkauannya dan menekan luas daerah 
blank spot. Selain itu ketersediaan kanal untuk melayani panggilan maupun permintaan akses data dan kualitas sinyal terima yang baik menjadi penentu kualitas suatu jaringan akses radio.

Dengan meningkatnya jumlah pelanggan dan permintaan berbagai jenis layanan menuntut ketersediaan coverage, kapasitas dan kualitas jaringan komunikasi bergerak yang handal. Pembangunan BTS baru diperlukan agar operator mampu mencakup area yang lebih luas, menyediakan kapasitas trafik yang mencukupi dengan kualitas jaringan yang baik. Namun demikian pembangunan BTS baru sering mengalami permasalahan seperti biaya yang mahal dan membutuhkan waktu yang cukup lama untuk mendapatkan ijin dari pemerintah maupun warga setempat. Proyek swap dan modernisasi di PT. XL Axiata Area Jawa Tengah bagian Utara merupakan sebuah proyek yang akan menukar perangkat 3G yang sebelumnya menggunakan BTS 3900 milik Huawei menjadi RBS 6000 milik Ericsson dan melakukan modernisasi perangkat 2G RBS 2000 menjadi RBS 6000.

Kinerja jaringan radio ketika beroperasi dimonitor dengan nilai key performance indicators (KPI) [1]. Parameter KPI yang berkaitan dengan kualitas voice didasarkan pada statistik yang dihasilkan oleh jaringan yang bisa diperoleh dengan metode drive test. Ukuran kualitas adalah BER (bit error rate), FER (frame error rate) dan CDR (call drop rate). CDR juga berkaitan dengan call success rate (CSR) dan handover success rate.

Penggantian perangkat BTS dapat meningkatkan kapasitas, karena penambahan Transmitter-Receiver (TRX) dalam setiap modul Digital Radio Unit (DRU) di jaringan 2G dan Channel Element (CE) dalam setiap modul WCDMA Radio Filter Unit (WRFU) arah uplink/downlink (UL/DL) pada jaringan 3G. Digital unit yang dipakai pada RBS 6000 adalah Digital Unit for WCDMA (DUW). Perbaikan dari segi kualitas diharapkan terpenuhi pada jaringan $2 \mathrm{G}$ dan $3 \mathrm{G}$ karena sudah dalam brand yang sama dan menjadi Single RAN (Radio Access Network). Seperti halnya pada coverage dan kualitas, untuk menguji kapasitas jaringan setelah proses swap dan modernisasi, diperlukan juga data yang dikumpulkan dari drive test maupun dari database jaringan. Aspek yang penting untuk kapasitas adalah dropped call dan congestion rate.

Hasil penelitian unjuk kerja jaringan seluler dengan proyek swap dan modernisasi ditinjau dari segi peningkatan coverage telah dibahas dalam [2]. Makalah tersebut melaporkan hasil peningkatan pada nilai $R x$ Level dan nilai RSCP sebagai parameter kuat sinyal terima masing-masing pada jaringan $2 \mathrm{G}$ dan $3 \mathrm{G}$. Dilaporkan juga perluasan jarak jangkauan sel sebagai akibat peningkatan kuat sinyal terima tersebut. Oleh karena itu dalam makalah ini, pembahasan akan difokuskan pada peningkatan kinerja dari aspek kualitas dan kapasitas pada jaringan seluler PT. XL Axiata Area Jawa Tengah bagian Utara setelah proyek swap dan modernisasi.

Dalam bagian berikutnya yaitu bagian 2 akan dijelaskan metode penelitian yang telah dilakukan. Selanjutnya hasil dan analisis penelitian dibahas pada bagian 3 dan ditutup kesimpulan pada bagian 4 .

\section{Metode Penelitian}

\subsection{Kondisi Daerah yang Diteliti}

Penelitian dilakukan pada jaringan PT. XL Axiata cluster D5 di daerah Ungaran Jawa Tengah, seperti terlihat pada Gambar 1. Pada cluster D5 terdapat 24 site 2G dan 21 site 3G. 
Analisis Peningkatan Kualitas dan Kapasitas Jaringan Seluler PT. XL Axiata pada Area Jawa Tengah bagian Utara melalui Proyek Swap dan Modernisasi Eva Yovita Dwi Utami, Pravita Ananingtyas Hanika

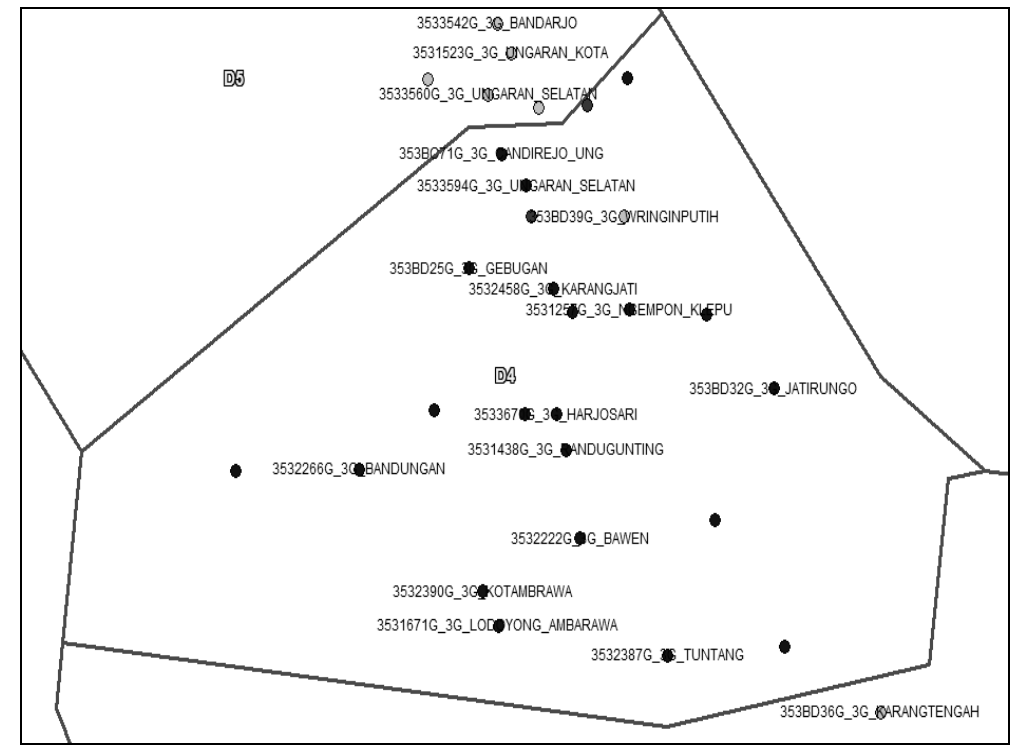

Gambar 1. Peta Cluster D5 PT.XL Axiata

\subsection{Metode Pengumpulan Data}

Pengumpulan data diperoleh dari hasil drive test dan database SQL Server PT. XL Axiata Tbk Semarang. Drive test merupakan pengumpulan data yang dilakukan pada saat berada di luar ruangan (outdoor) dan dilakukan dengan berkendara (drive) menggunakan mobil [3]. Parameter yang diukur pada saat drive test adalah $R x$ Level, $R x$ Qual, RSCP, Ec/No dan SQI [4]. Parameter yang diukur untuk melihat voice quality saat panggilan adalah Call Drop Rate dan Handover Success Rate yang diperoleh dari report generator hasil drive test pada software TEMS Investigation 11.0. Data yang diambil dari database SQL Server meliputi SDCCH, TCH dan Payload Data Services. Pengambilan data dilakukan sebelum dan setelah dilakukan proyek swap dan modernisasi. Parameterparaemeter penelitian dijelaskan di bawah ini.

\subsubsection{Rx Qual}

Rx Qual merupakan tingkat kualitas sinyal 2G dari sinyal termodulasi yang diterima MS, yang merupakan konversi nilai BER [3][4]. Rentang nilai Rx Qual PT. XL Axiata ditunjukkan pada Tabel 1. Persentase peningkatan Rx Qual dinyatakan dalam Persamaan (1).

$$
\text { Perbaikan_RxQual }=\frac{\%\left(\text { RxQual } \leq 4_{-} \text {sesudah }\right)-\%\left(\text { RxQual } \leq 4_{-} \text {sebelum }\right)}{100-\%\left(\text { RxQual } \leq 4_{-} \text {sebelum }\right)} \times 100 \%
$$

Tabel 1. Rentang Nilai Rx Qual, Ec/No dan SQI

\begin{tabular}{|c|c|c|c|c|c|c|c|c|}
\hline \multicolumn{3}{|c|}{ Rx Qual } & \multicolumn{3}{c|}{$E_{\mathrm{c} / N_{0}}$} & \multicolumn{3}{c|}{ SQI } \\
\hline $\begin{array}{c}\text { Level } \\
\text { Rx Qual }\end{array}$ & $\begin{array}{c}\text { Simbol } \\
\text { Warna }\end{array}$ & Keterangan & $\begin{array}{c}E_{\mathrm{c}} / N_{0} \\
(\mathrm{~dB})\end{array}$ & $\begin{array}{c}\text { Simbol } \\
\text { Warna }\end{array}$ & Keterangan & $\begin{array}{c}\text { Level } \\
\text { SQI }\end{array}$ & $\begin{array}{c}\text { Simbol } \\
\text { Warna }\end{array}$ & Keterangan \\
\hline $6 \mathrm{~s} / \mathrm{d} 8$ & Merah & Buruk & $-10 \mathrm{~s} / \mathrm{d} 0$ & $\begin{array}{c}\text { Biru } \\
\text { Tua }\end{array}$ & Baik & $-20 \mathrm{~s} / \mathrm{d} 0$ & Merah & Buruk \\
\hline $4 \mathrm{~s} / \mathrm{d} 8$ & Kuning & Cukup & $\begin{array}{c}-15 \mathrm{~s} / \mathrm{d}- \\
10\end{array}$ & $\begin{array}{c}\text { Biru } \\
\text { Muda }\end{array}$ & Cukup & $0 \mathrm{~s} / \mathrm{d} 18$ & Kuning & Cukup \\
\hline $0 \mathrm{~s} / \mathrm{d} 4$ & Hijau & Baik & $\begin{array}{c}-34 \mathrm{~s} / \mathrm{d}- \\
15\end{array}$ & $\begin{array}{c}\text { Abu- } \\
\text { abu }\end{array}$ & Buruk & $18 \mathrm{~s} / \mathrm{d} 30$ & Hijau & Baik \\
\hline
\end{tabular}




\subsection{2. $E_{c} / N_{0}$}

Level interferensi yang berasal dari sel-sel lain dalam jaringan UMTS sering dikuantitaskan oleh perbandingan energi per chip terhadap daya total yang diterima atau disingkat $E_{c} / N_{0}$ [5]. Daya total terima ini mengandung sinyal dari penginterferensi sehingga diacu sebagai derau terhadap sinyal yang diinginkan. Rentang nilai $E_{c} / N_{o}$ yang digunakan oleh PT. XL Axiata Tbk dapat dilihat pada Tabel 1. Persentase peningkatan $E_{c} / N_{0}$ dinyatakan dalam Persamaan (2).

Perbaikan_ $E_{c} / N_{0}=\frac{\%\left(E_{c} / N_{0} \geq-18 d B_{-} \text {sesudah }\right)-\%\left(E_{c} / N_{0} \geq-18 d B_{-} \text {sebelum }\right)}{100-\%\left(E_{c} / N_{0} \geq-18 d B_{-} \text {sebelum }\right)} \times 100 \%$ (2)

\subsubsection{Speech Quality Index (SQI)}

SQI merupakan taksiran kualitas pembicaraan yang dirasakan oleh pendengar [3][4]. SQI merupakan parameter yang terdapat pada software TEMS Investigation. Nilai dari parameter SQI ini didasarkan pada nilai FER, BER dan speech codec yang digunakan. Rentang nilai SQI yang digunakan oleh PT. XL Axiata Tbk dapat dilihat di Tabel 1.

\subsubsection{Call Drop Rate (CDR)}

Call Drop Rate (CDR) merupakan persentase perbandingan antara dropped call dengan panggilan yang terlayani. Dropped call adalah suatu kondisi bilamana pembicaraan yang sedang berlangsung terputus sebelum user berniat mengakhiri pembicaraan [1]. Hal tersebut membuat ketidaknyamanan pelanggan saat berkomunikasi atau melakukan panggilan. Untuk mengetahui banyaknya call drop dan call setup dapat diketahui dari hasil report generator pada software TEMS Investigation 11.0.

\subsubsection{Handover Success Rate (HSR)}

Handover Succes Rate merupakan persentase jumlah handover yang berhasil terjadi dibandingkan permintaan handover[1]. Saat melakukan panggilan dan dengan adanya mobilitas user, MS berpindah dari suatu sel ke sel yang lain, oleh karena itu diperlukan handover agar tidak terjadi dropped call. Idealnya nilai HSR adalah 100\% karena jika kurang dari $100 \%$ terdapat kemungkinan terjadinya dropped call. Kegagalan handover dapat terjadi karena tidak tercantumnya BTS tujuan pada neighboor list BTS semula sehingga kedua BTS tidak saling mengenal. Efek ping-pong dapat dialami MS pada proses handover dikarenakan kedua BTS mempertahankan melayani MS. Kegagalan dapat juga terjadi jika pada saat dilaksanakan handover sel tujuan mengalami overload traffic sehingga panggilan dipertahankan oleh BTS hingga nilai kuat sinyal jatuh di bawah minimum dan akhirnya terjadi pemutusan panggilan.

\subsubsection{TCH Congestion Rate}

TCH Congestion Rate merupakan jumlah panggilan yang ditolak (blocked call) dibandingkan dengan jumlah permintaan untuk mengakses TCH yang terjadi saat busy hour[1]. TCH Congestion terjadi jika kanal TCH tidak tersedia. 


\section{Hasil dan Analisis Penelitian}

\subsection{Analisis Peningkatan Kualitas}

\subsubsection{Analisis Hasil Drive Test dengan Parameter Rx Qual}

Hasil pengolahan drive test pada MapInfo Profesional 11.0 yang dilakukan pada cluster D5 dengan parameter Rx Qual ditunjukkan pada Gambar 2. Terlihat adanya perbedaan warna rentang $R x$ Qual di beberapa titik. Rx Qual merupakan parameter tingkat kualitas jaringan 2G. Semakin kecil nilai $R x$ Qual maka semakin baik pula kualitas jaringan 2G karena tingkat BER semakin kecil. Hasil pengolahan data drive test Rx Qual sebelum dan sesudah proyek swap dan modernisasi dapat dilihat pada Tabel 2.

Tabel 2. Hasil Perbandingan Rx Qual Sebelum dan Sesudah Proyek Swap dan Modernisasi.

\begin{tabular}{|c|c|c|}
\hline Level Rx Qual & Sebelum (\%) & Sesudah (\%) \\
\hline 0 s.d. 4 & $80,76 \%$ & $85,34 \%$ \\
\hline 4 s.d. 8 & $8,98 \%$ & $7,62 \%$ \\
\hline 6 s.d. 8 & $10,25 \%$ & $7,08 \%$ \\
\hline
\end{tabular}

Tabel 2 memperlihatkan pada level $R x$ Qual 0 sampai dengan 4 terjadi peningkatan sebesar 4,58\%. Level tersebut menunjukkan tingkat kualitas sinyal 2G yang baik. Pada cluster D5 sebelumnya terdapat $80,76 \%$ area yang memiliki kualitas sinyal yang baik, namun di sisi lain masih cukup banyak area dengan $R x$ Qual pada rentang 6 sampai dengan 8 atau kualitas sinyalnya buruk. Pada hasil tersebut juga dapat dilihat berkurangnya persentase pada tingkat kualitas $2 \mathrm{G}$ yang buruk sebesar 3,17\%. Secara keseluruhan peningkatan kualitas sinyal 2G pada cluster D5 dengan perhitungan sesuai Persamaan (1) adalah 23,85\%.

\subsubsection{Analisis Hasil Drive Test dengan Parameter $E_{\mathrm{c}} / N_{0}$}

Tingkat kualitas sinyal $3 \mathrm{G}$ diukur dengan parameter $E_{\mathrm{c}} / N_{0}$ yang mempunyai rentang yang menggambarkan tingkat kualitas 3G. Hasil perbandingan nilai $E_{\mathrm{c}} / N_{0}$ dapat dilihat pada Tabel 3. Tabel 3 menunjukkan bahwa setelah adanya proyek swap dan modernisasi seluruh area cluster D5 sudah dicakup oleh tingkat kualitas sinyal 3G yang bagus yaitu pada rentang $-10 \mathrm{~dB}$ sampai dengan $0 \mathrm{~dB}$. Sehingga total perbaikan kualitas sinyal 3G pada area cluster D5 berdasarkan Persamaan (2) adalah sebesar 4,02\%.

Tabel 3. Hasil Perbandingan $E_{\mathrm{c}} / N_{0}$ Sebelum dan Sesudah Proyek Swap dan Modernisasi.

\begin{tabular}{|c|c|c|}
\hline $\begin{array}{c}\text { Rentang } E_{d} / N_{o} \\
(\mathrm{~dB})\end{array}$ & Sebelum (\%) & Sesudah (\%) \\
\hline-10 s.d. 0 & $88,83 \%$ & $100 \%$ \\
\hline-15 s.d. -10 & $7,15 \%$ & - \\
\hline-34 s.d. -15 & $4,01 \%$ & - \\
\hline
\end{tabular}

\subsubsection{Analisis Hasil Drive Test dengan Parameter SQI}

SQI merupakan kualitas sinyal yang dirasakan langsung oleh pendengar. Dari hasil penelitian SQI sebelum dan sesudah proyek swap dan modernisasi terlihat banyak perbedaan. Hal ini dapat dilihat dari plot hasil drive test pada MapInfo Profesional 11.0 pada Gambar 4 dan hasil perbandingan nilai SQI pada Tabel 4. 
Tabel 4. Hasil Perbandingan SQI Sebelum dan Sesudah Proyek Swap dan Modernisasi.

\begin{tabular}{|c|c|c|}
\hline Level SQI & Sebelum (\%) & Sesudah (\%) \\
\hline 18 s.d. 30 & $66,55 \%$ & $67,22 \%$ \\
\hline 0 s.d. 18 & $5,60 \%$ & $31,76 \%$ \\
\hline -20 s.d. 0 & $27,87 \%$ & $1,00 \%$ \\
\hline
\end{tabular}
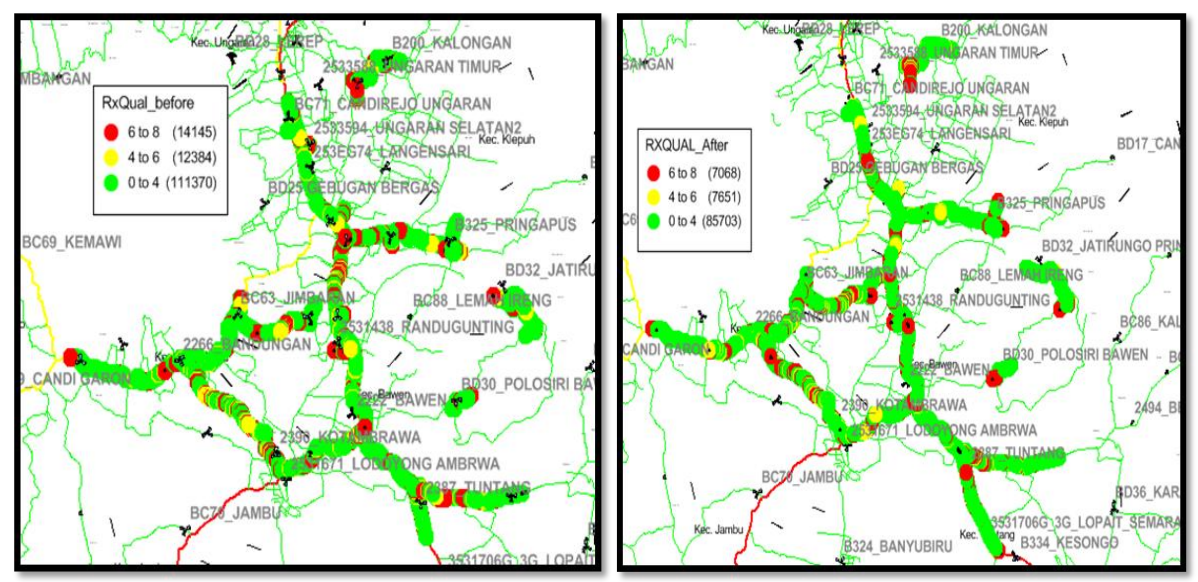

Gambar 2. Hasil Plot Rx Qual (a) sebelum proyek swap dan modernisasi (b) setelah proyek swap dan modernisasi.
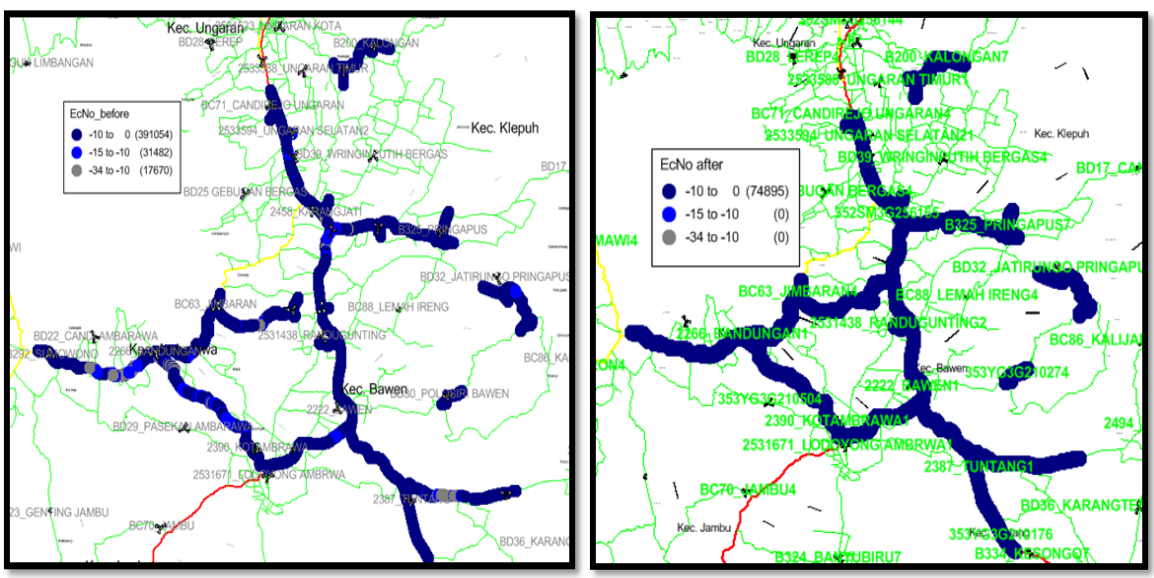

Gambar 3. Hasil Plot $E_{d} / N_{o}$ (a) sebelum proyek swap dan modernisasi (b) setelah proyek swap dan modernisasi.
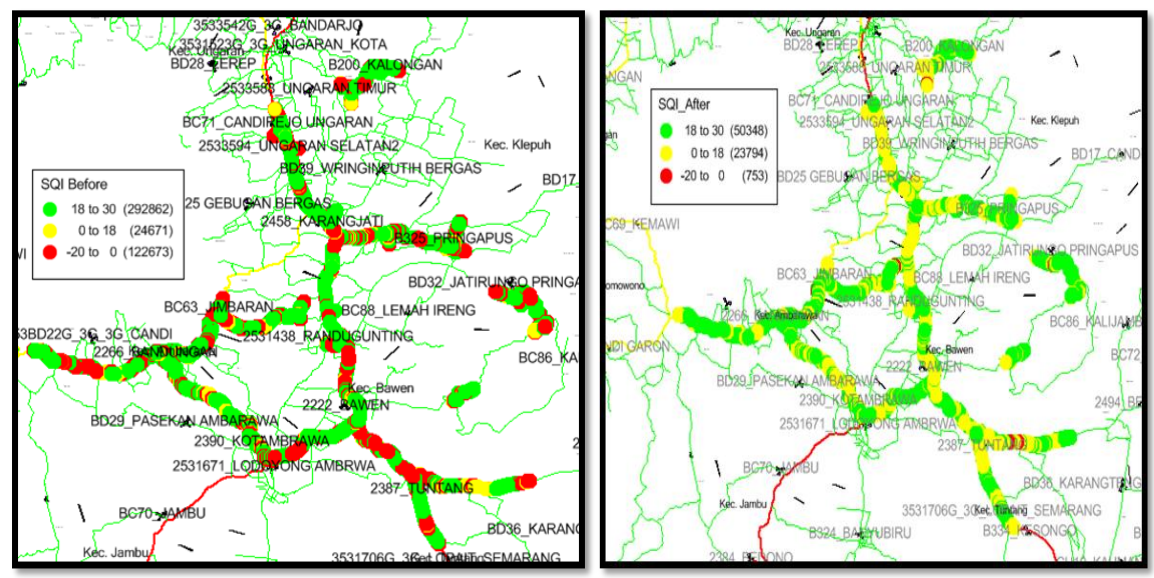

Gambar 4. Hasil Plot SQI (a) sebelum proyek swap dan modernisasi (b) setelah proyek swap dan modernisasi. 
Analisis Peningkatan Kualitas dan Kapasitas Jaringan Seluler PT. XL Axiata pada Area Jawa Tengah bagian Utara melalui Proyek Swap dan Modernisasi

Eva Yovita Dwi Utami, Pravita Ananingtyas Hanika

Pada level SQI 18 sampai dengan 30 terjadi peningkatan sebesar 0,69\% dimana pada rentang nilai SQI ini merupakan tingkat SQI paling baik. Level paling buruk yaitu -20 sampai dengan 0 mengalami penurunan sebesar $26,86 \%$. Nilai SQI berdampak pada sinyal yang didengar oleh pendengar, yakni suara akan terdengar terputus-putus. Setelah adanya proyek swap dan modernisasi nilai SQI yang buruk yakni pada level -20 sampai dengan 0 berkurang drastis menjadi $1 \%$ saja. Sehingga pada cluster D5 peningkatan kualitas $3 \mathrm{G}$ dapat dirasakan oleh pendengar.

\subsubsection{Analisis Call Drop Rate}

Banyaknya call drop dan call setup dapat diketahui dari report generator pada software TEMS Investigation 11.0. Berdasarkan hasil tersebut diketahui bahwa setelah adanya proyek swap dan modernisasi tidak ada dropped call pada cluster D5 seperti terlihat pada Tabel 5. Dropped call dapat dipengaruhi oleh Rx Level dan Rx Qual. Cluster D5 mengalami peningkatan kuat sinyal sebagaimana dilaporkan dalam [2\} dan peningkatan kualitas sinyal 2G sehingga hal ini berpengaruh pada berkurangya panggilan yang terputus di area cluster D5.

Tabel 5. Hasil Perbandingan Dropped Call Sebelum dan Sesudah Proyek Swap dan Modernisasi.

\begin{tabular}{|c|c|c|}
\hline & Sebelum & Sesudah \\
\hline Call Dropped & 4 & - \\
\hline Call Setup & 87 & 93 \\
\hline Call Drop Rate & $4,59 \%$ & $0 \%$ \\
\hline
\end{tabular}

\subsubsection{Analisis Handover Success Rate}

Hasil perbandingan HSR sebelum dan sesudah proyek swap dan modernisasi yang diolah dengan report generator drive test pada software TEMS Investigation 11.0 pada cluster D5 dapat dilihat pada Tabel 6. Dari hasil tersebut dapat dilihat bahwa target HSR yaitu $100 \%$ dapat terpenuhi. HSR juga erat hubungannya dengan kuat sinyal. Dalam [2\}, kuat sinyal setelah adanya proyek swap meningkat sehingga mempengaruhi nilai HSR menjadi lebih baik.

Tabel 6. Hasil Perbandingan HSR Sebelum dan Sesudah Proyek Swap dan Modernisasi.

\begin{tabular}{|c|c|c|}
\hline & Sebelum & Sesudah \\
\hline Handover Success & 149 & 167 \\
\hline Handover Attempt & 153 & 167 \\
\hline HSR & $97,38 \%$ & $100 \%$ \\
\hline
\end{tabular}

Kualitas jaringan 2G dan 3G dapat dilihat dari parameter hasil drive test yaitu Rx Qual, $E_{c} / N_{0}$ dan SQI. Selain itu kualitas panggilan juga dapat dilihat dari handover success rate dan call drop rate. Peningkatan kualitas pada jaringan 2G berdasarkan parameter Rx Qual pada cluster D5 sebesar 23,85\%. Sedangkan pada jaringan 3G di cluster D5 dilihat dari parameter $E_{c} / N_{0}$ mengalami peningkatan sebesar 4,02\% sehingga seluruh area cluster D5 sudah memiliki tingkat kualitas di atas -10 dB. Peningkatan SQI di cluster D5 cukup signifikan yaitu sebesar $96,38 \%$ pada level SQI di atas -20 .

Kualitas panggilan berdasarkan handover success rate dan call drop rate juga meningkat. Hal ini ditunjukkan dengan penurunan call drop rate dari 4,59\% menjadi $0 \%$ dan peningkatan handover success rate sebesar 2,62\% setelah proyek swap dan modernisasi. 


\subsection{Analisis Peningkatan Kapasitas}

\subsubsection{Peningkatan Kapasitas Jaringan 2G}

Adanya penggantian perangkat 2G dari RBS 2000 menjadi RBS 6000 mempunyai dampak penambahan TRX sehingga kapasitas juga bertambah. Arsitektur hardware RBS 2000 hanya memiliki 12 TRX dengan konfigurasi 4 TRX untuk masing-masing sektor. Sedangkan pada RBS 6000 memiliki 24 TRX sehingga konfigurasi masing-masing sektor maksimal dapat mempunyai 8 TRX. Artinya terjadi penambahan sebesar 12 TRX dari sebelumnya.

Perhitungan di atas membuktikan bahwa adanya penambahan kapasitas sebesar 96 time slot atau bisa juga dikatakan bahwa satu RBS dapat menambah 96 ketersediaan panggilan untuk pelanggan.

Peningkatan kapasitas jaringan 2G juga dibuktikan dari data statistik PT. XL Axiata Tbk yaitu data trafik TCH dan trafik payload data $2 \mathrm{G}$ sebelum dan sesudah proyek swap dan modernisasi.. Sebelumnya pada rentang waktu dua minggu trafik payload data total adalah 907816,1 Erlang dan setelah proyek swap dan modernisasi terjadi peningkatan pemakaian payload data $2 \mathrm{G}$ sebesar 80605,4 Erlang. Untuk trafik TCH sebelum proyek swap dan modernisasi total trafik TCH sebesar 135306,1 Erlang dan sesudah proyek swap dan modernisasi menjadi 89038,9 Erlang. Artinya terdapat penurunan trafik TCH setelah adanya proyek swap dan modernisasi. Hal ini dimungkinkan karena pelanggan banyak beralih menggunakan data service dibandingkan dengan penggunaan voice. Secara keseluruhan, trafik yang ditangani meningkat setelah proyek swap dan modernisasi.

\subsubsection{Peningkatan Kapasitas Jaringan 3G}

Peningkatan kapasitas 3G dilihat dari jumlah peningkatan Channel Element (CE). Jika pada GSM dikenal istilah kanal/TCH maka dalam WCDMA dikenal dengan istilah CE. Tabel penggunaan CE dapat dilihat pada Tabel 7.

Dari data yang diambil dari database statistik PT. XL Axiata Tbk dapat diketahui bahwa terjadi perubahan jumlah CE di beberapa site setelah adanya proyek swap dan modernisasi. Tabel 7 memperlihatkan bahwa terdapat 6 site dengan pertambahan CE dari sebelumnya $256 \mathrm{CE}$ per modul WRFU (UL/DL) menjadi $384 \mathrm{CE}$ per modul DUW (UL/DL). Hal ini membuktikan adanya peningkatan jumlah kanal pada jaringan 3G yang dapat dipakai oleh pelanggan

Tabel 7. Jumlah CE Sebelum dan Sesudah Proyek Swap dan Modernisasi.

\begin{tabular}{|c|c|c|}
\hline NodeB_id & Jumlah CE Sebelum & Jumlah CE Sesudah \\
\hline 3531251G & 384 & 512 \\
\hline $3531266 \mathrm{G}$ & 384 & 512 \\
\hline $3531523 \mathrm{G}$ & 384 & 512 \\
\hline $3531636 \mathrm{G}$ & 384 & 512 \\
\hline 3533588G & 384 & 512 \\
\hline
\end{tabular}

Peningkatan jumlah kapasitas pada jaringan 3G juga dibuktikan dari data speech traffic dan trafik payload data 3G. Dari data yang diambil dari database statistik didapatkan adanya pertambahan trafik payload data setelah adanya proyek swap dan modernisasi sebesar 36453062 Erlang. Sedangkan speech traffic sebelum proyek swap dan modernisasi lebih banyak yaitu sebesar 4327,771 Erlang dan setelah proyek swap dan modernisasi menurun menjadi 2920,417 Erlang. Namun demikian secara total, trafik yang ditangani pada jaringan 3G meningkat setelah proyek swap dan modernisasi 
Analisis Peningkatan Kualitas dan Kapasitas Jaringan Seluler PT. XL Axiata pada Area Jawa Tengah bagian Utara melalui Proyek Swap dan Modernisasi

Eva Yovita Dwi Utami, Pravita Ananingtyas Hanika

\subsubsection{TCH Congestion Rate}

Perbandingan nilai TCH Congestion Rate sebelum dan sesudah proyek swap dan modernisasi ditunjukkan pada Tabel 8. Adanya kenaikan kapasitas pada RBS selain dengan dibuktikan adanya kenaikan trafik dapat dibuktikan juga dengan berkurangnya TCH Congestion Rate. Sebelumnya, nilai TCH Congestion Rate lebih besar daripada 50\%, sedangkan setelah adanya proyek swap dan modernisasi nilai TCH Congestion Rate menjadi kurang dari 10\%. Hal ini menunjukkan kapasitas yang disediakan jaringan mampu menekan jumlah blocked call atau adanya penambahan kanal TCH mampu mencukupi permintaan trafik pada site tersebut.

Tabel 8. Perbandingan Nilai TCH Congestion Rate sebelum dan sesudah Proyek Swap dan Modernisasi.

\begin{tabular}{|c|c|c|c|}
\hline CELL ID & SITE & $\begin{array}{c}\text { TCH_Congestion Sebelum } \\
(\%)\end{array}$ & $\begin{array}{c}\text { TCH_Congestion Sesudah } \\
(\%)\end{array}$ \\
\hline SM14381 & Randugunting & 91,65882 & 5,186495 \\
\hline SM41714 & Randugunting2 & 81,31013 & 0,933831 \\
\hline 23257 & Pringapus & 70,85109 & 0,348554 \\
\hline 49868 & Candirejo_Ung & 59,48973 & 6,321349 \\
\hline
\end{tabular}

\section{Kesimpulan}

Peningkatan kualitas jaringan setelah proyek swap dan modernisasi ditunjukkan dari hasil drive test yaitu perbaikan parameter Rx Qual sebesar $23,85 \%$, perbaikan $E_{c} / N_{o}$ sebesar $4,02 \%$ dan perbaikan SQI sebesar 96,38\% pada cluster D5. Selain itu diperoleh peningkatan kualitas dari segi penurunan persentase Call Drop Rate dan kenaikan persentase Handover Success Rate.

Peningkatan kapasitas setelah adanya proyek swap dan modernisasi diperoleh dari penambahan kanal karena adanya perubahan arsitektur hardware, BTS 3900 dan RBS 2000 menjadi RBS 6000. Sebelumnya, BTS untuk 2G hanya mempunyai 12 TRX per modul DRU menjadi 24 TRX per modul DRU dan BTS untuk 3G sebelumnya 256 CE per modul WRFU (UL/DL) menjadi 512 CE per modul DUW (UL/DL). Peningkatan kapasitas ini dibuktikan dengan hasil pengukuran trafik yang mampu ditangani jaringan setelah adanya proyek swap dan modernisasi yaitu bertambah sebesar 34328,21 Erlang untuk 2G dan 36451674 Erlang untuk 3G. Penambahan kapasitas juga menurunkan terjadinya blocked call, hal ini ditunjukkan dengan berkurangnya TCH Congestion Rate.

\section{Daftar Pustaka}

[1] A.R. Misra., Fundamentals of Cellular Network Planning \& Optimiation, John Wiley \& Sons, Ltd, 2004

[2] E.Y.D. Utami, P.A. Hanika, "Peningkatan Coverage pada Jaringan Seluler PT. XL Axiata di Area Jawa Tengah Bagian Utara melalui Proyek Swap dan Modernisasi", Jurnal Rekayasa Elektrika, submitted.

[3] L. Wardhana, 2G/3G RF Planning and Optimization for Consultant, nulisbuku.com, 2011.

[4] 2G Drive Test Methodology, Reporting and Study Case, Training Material, Floatway System, 2011.

[5] Qualcomm Engineering Services Group (ESG), WCDMA Network Planning and Optimization, ESG 80-W0853-1 Revision B, May 2006. 